Dishonest Assistance and Accessory Liability

Paul S. Davies, Accessory Liability, Oxford: Hart Publishing, 2015, 294 pp, hb $£ 54.99$

\title{
INTRODUCTION
}

There are numerous examples within private law where a third party can be held liable for playing a role in another person's breach of duty. This can be relevant in claims such as 'dishonest assistance' and 'inducing a breach of contract'. ${ }^{1}$ The language of each of these forms of liability seems to imply that they focus on different types of involvement. For example, assistance is not necessarily synonymous with inducement. This has resulted in 'pockets' of third party liability, whereby there are separate formulations of third party liability depending on the primary wrong (a crime or a breach of duty committed by another person). ${ }^{2}$ Nonetheless, it has been suggested by a number of commentators that it is possible to draw together claims against those who involve themselves with primary wrongs under the concept of 'accessory liability' ${ }^{3}$ Paul Davies' book, Accessory Liability, provides a welcome analysis which seeks to provide coherence to 'accessory liability' by demonstrating that a unified approach can be used to determine the way in which such cases are treated.

Whether or not one agrees that it is possible to unify the pockets of accessory liability, it is worth stating that Davies' book is a thoroughly researched and insightful publication. This book presents a challenging, and powerful, argument that the various forms of accessory liability can be drawn together, and Davies' framework provides a clear way towards achieving that goal. In this review, the major point of divergence with Davies' proposition is that the inclusion of the equitable action for dishonest assistance creates a number of problems for this general concept of accessory liability. Although the mere historical divide between the courts of equity and common law does not justify differentiating between the forms of third party liability found in both sources of law, there remain important distinctions in the underlying aims and goals in equity from those at common law. It is tentatively suggested in this essay that the reason for the distinct nature of third party liability in equity reflects the nature of equitable duties. The defining nature of an equitable obligation is the control that a trustee or fiduciary has over the interests of another. ${ }^{4}$ This element of control is important in determining the position of third parties for two reasons. One reason is that that the beneficiary or principal is in a vulnerable position because of the delegation of control given to the duty holder, and so there is a need to prevent third parties from taking advantage of these relationships even where their actions assist, rather than cause, breaches of equitable duties. ${ }^{5}$ The other reason is that the trustee or fiduciary's ability to engage third parties, which is inherent in the control afforded to

\footnotetext{
${ }^{1}$ For dishonest assistance, see Royal Brunei Airlines Sdn Bhd v Tan [1995] 2 AC 378 (PC) 384-385 (Lord Nicholls); for inducing breach of contract, see OBG Ltd v Allan [2007] UKHL 21, [2008] 1 AC 1 [39]-[44] (Lord Hoffmann).

${ }^{2}$ P. S. Davies, Accessory Liability (Oxford: Hart, 2015) 1-2.

${ }^{3}$ P. Sales, 'The Tort of Conspiracy and Civil Secondary Liability' 49 CLJ (1990) 491; C. Harpum, 'The Uses and Abuses of Constructive Trusts: The Experience of England and Wales' 1 Edinburgh L Rev (1997) 437, 462; J. Dietrich, 'The Liability of Accessories under Statute, in Equity, and in Criminal Law: Some Common Problems and (Perhaps) Common Solutions' [2010] 34 Melb U L Rev 106.

4 J. Getzler, 'Ascribing and Limiting Fiduciary Obligations' in A.S. Gold and P.B. Miller (eds), Philosophical Foundations of Fiduciary Law (Oxford: OUP, 2014), 43.

${ }^{5}$ H. Carty, 'Joint Tortfeasance and Assistance Liability' (1999) 19 Legal Studies 489, 511-512.
} 
those who hold such positions, would be undermined if third parties were exposed to potential liability for involvement in wrongdoing by others. ${ }^{6}$

These aims are reflected in the way in which equity formulates claims against those who assist in breaches of equitable duties. First, equity requires a high level of moral culpability, which justifies liability even for 'weaker' causal links with the primary wrong such as omissions. ${ }^{7}$ It is even possible for a third party to be held liable in cases where no causal link is evident, such as where assistance is provided after a breach of duty has occurred. ${ }^{8}$ In contrast, under the tort of inducing a breach of contract, a strong causal link must be demonstrated through the 'inducement' of the primary wrongdoer. ${ }^{9}$ Second, by only imposing liability on third parties for high levels of moral culpability, this provides an important level of protection for third parties. For example, the mental element required in equity for a third party who assists a breach of an equitable duty is one of dishonesty. Thus, equity's approach to third party liability is quite distinct from the approach taken in other instances, such as inducing a breach of contract where a less stringent mental element is required. ${ }^{10}$ Given these differences in approach, the incorporation of dishonest assistance would not only require drastic changes to the way in which claims outside of equity operate but it also potentially undermines the cohesion of the core concept of accessory liability developed in Davies' book. Moreover, it illustrates the importance of recognising the different aims and principles of equity and common law.

\section{THE SCOPE OF THE BOOK}

'Accessory liability' does not include all instances of third party liability and so it will be useful at this stage to clarify the use of the term 'third party liability' in this essay. The term 'third party' is commonly used in two situations. The first use of the phrase 'third party' may refer to any party who is neither a claimant nor a defendant in litigation, but who has nonetheless played a significant role in the requirements for a claim. ${ }^{11}$ An example would be the 'intervening act' of a 'third party'. ${ }^{12}$ The second use of the term 'third party' arises when referring to someone who is external to a legal relationship and who may potentially be liable for interfering with the rights of the claimant. For example, upon its establishment, a trust involves a legal relationship between trustee and beneficiary and anyone outside of that relationship stands as a third party. ${ }^{13}$ Similarly, in the law of contract, a third party does not owe the same contractual obligations as the contracting parties (167-168). In this essay, the term third party is used in the

\footnotetext{
${ }^{6}$ Barnes $v$ Addy (1873-74) LR 9 Ch App 244 (CA) 252 (Selborne LC).

${ }^{7}$ See M. Moore, Causation and Responsibility: An Essay in Law, Morals, and Metaphysics (Oxford: OUP, 2009) 139. Moore also contends that an omission should not be regarded as a 'cause', 139-140.

${ }^{8}$ It has been argued by Dietrich that assistance merely provides a 'weak' causal link, see J. Dietrich,

'Accessorial Liability in the Law of Torts' (2011) 31 Legal Studies 231, 242-244.

${ }^{9}$ Allen v Flood [1898] AC 1 (HL) 121 (Lord Herschell) and Quinn v Leathem [1901] AC 495 (HL) 510 (Lord Macnaghten).

${ }^{10}$ See Lord Millett's dissenting judgment in Twinsectra v Yardley [2002] UKHL 12, [2002] 2 AC 164, [126][134].

${ }^{11}$ Eg C. McIvor, Third Party Liability in Tort (Oxford: Hart, 2006).

${ }^{12} \mathrm{Eg}$ the actions of the police inspector in Knightley $v$ Johns [1982] 1 WLR 349 (CA).

${ }^{13}$ Except where there may be a trustee de son tort; Barnes $v$ Addy (1873-74) LR 9 Ch App 244 (CA), 251-252.

Where this happens, the third party loses their status as a third party and instead is treated as a primary duty holder.
} 
latter sense by referring to a third party who is someone that is external to an existing legal relationship.

There are also various means by which a third party may be liable for interfering with the rights of the claimant, but which nonetheless fall outside of the scope of Davies' formulation of accessory liability. For example, a claimant may be injured because of a breach of duty by a primary wrongdoer, but at the same time, the wrongdoer's employer might also be held responsible under the doctrine of vicarious liability. ${ }^{14}$ According to Davies, we would distinguish this type of liability as the third party is strictly liable (58-60). Another example is where a defendant has a duty to prevent a third party from causing harm to the claimant but fails in performing their duty. One such case is Home Office v Dorset Yacht, where the defendants were liable for allowing the escape of the young offenders who damaged the claimant's property. ${ }^{15}$ This is distinguished from accessory liability on the basis that the defendant owed a free standing duty independent of the defendant's wrongdoing. For example, in the Dorset Yacht case, the Home Office was potentially liable even if the young offenders had acted in a way that was not regarded as a primary wrong. Davies argues that, therefore, it is essential to keep strict liability regimes and free-standing forms of liability separate from accessory liability (56-60). The result is liability that is 'accessorial'; it is contingent upon a primary wrong committed by another person, as where a breach of trust or breach of contract occurs.

\section{THE CENTRAL APPROACH}

In developing accessory liability, Davies sets out a general approach that draws upon principles of accessory liability in the criminal context. The analysis breaks down accessory liability into a conduct element and a mental element. Both of these elements will be explored in the following sections but, for present purposes, it will be useful to briefly set these out. First, the conduct element focuses on whether the defendant can be held responsible where their actions have made a substantial causal impact on a primary wrong (as where a defendant induces a breach of contract) (37-39). Second, the mental element requires the defendant to have knowledge that their conduct will 'constitute causative participation in the type of primary wrong actually committed' (43). Accessory liability requires a claimant to establish both elements which, according to Davies, provides a satisfactory means of preventing claims against those who may inadvertently become involved in the wrongs of others (13). Importantly, Davies' book firmly pins itself to a fusionist position by seeking to draw together claims developed in equity and common law $(8-10) .{ }^{16}$

\section{The Conduct Element}

For the purposes of developing the conduct element, Davies explores the terms aid, abet, counsel or procure. It is evident from this analysis that there is considerable overlap between some of these terms (22-31). Furthermore, it is also apparent that the terms aid, abet, counsel

\footnotetext{
${ }^{14}$ Eg Dubai Aluminium Co Ltd v Salaam [2002] UKHL 48, [2003] 2 AC 366.

15 [1970] AC 1004 (HL), discussed by Davies, above n 2, 57.

16 This is also evident when Davies approves of the fusionist approach to receipt-based liability, n 2 above, 91 92.
} 
or procure are not always coterminous with the concept of accessory liability developed in the book. It is concluded by Davies that the use of these terms creates the potential for confusion and conflict; however, the recurrent theme that underpins these conduct elements is that there is a link between the act of the defendant and the primary wrong (31). Davies goes on to argue that the conduct element can be addressed by asking whether the third party's activities have had a 'substantial causal impact upon the primary wrong and the infringement of victim's rights' (39). Although Davies contends that this broad test of 'substantial cause' can be applied across the board, the book also addresses the conduct question in separate chapters on equity, contract and tort.

Nonetheless, causation is a notoriously complex and controversial issue, and this complexity is bound to be exacerbated by the variances in terminology in the criminal context as well as its various applications in private law. For example, whilst the terminology of 'substantial cause' will be familiar for criminal lawyers, it may possibly cause some confusion for private lawyers. ${ }^{17}$ Substantial cause indicates that there must be more than a minimal contribution, which would indicate that it is akin to 'material contribution' to injury in the tort of negligence. There are two reasons why the concepts are distinct. First, whereas material contribution to injury is essentially a test of factual causation in negligence, ${ }^{18}$ substantial cause appears to incorporate questions of factual and legal causation. ${ }^{19}$ Second, in cases of material contribution to injury, the defendant's actions must have made some contribution to the overall extent of the harm suffered by the claimant. ${ }^{20}$ But the test of substantial cause adopted by Davies can include cases where the contribution of the defendant may have little impact on the primary wrong. ${ }^{21}$ Take for example a trustee who has transferred trust property into their bank account in breach of their equitable duty, and afterwards a third party assists in transferring the money through a series of bank accounts to prevent the beneficiary from recovering the property. ${ }^{22}$ Since the primary wrong had already been committed before any assistance, it is difficult to find a clear causal link between the assistance and the primary wrong. ${ }^{23}$ It can be questioned, therefore, whether such involvement can even be regarded as a 'substantial' cause. ${ }^{24}$ For these reasons, it has been contended elsewhere that the question of causation is inappropriate for accessory liability, as in many instances the primary wrong would have occurred regardless of the accessory's contribution. ${ }^{25}$ Dietrich and Ridge, for example, have recently contended that 'the courts have rarely concerned themselves with questions of causation in any accessorial context' ${ }^{26}$ These authors prefer the terminology of 'involvement' in the primary wrong. The issue, it is contended here, reflects one of the many difficulties of

\footnotetext{
${ }^{17}$ As noted by K. Burns et al, 'Australia: A Land of Plenty (of Legislative Legimes)' in M. Dyson (ed), Comparing Tort and Crime: Learning from across and within Legal Systems (Cambridge: CUP, 2015) 389-390. ${ }^{18}$ Williams v Bermuda Hospitals Board [2016] UKPC 4, [2016] AC 888, [47] (Lord Toulson).

${ }^{19} R v$ Hughes [2013] UKSC 56, [2013] 1 WLR 2461 [22]-[23] (Lord Hughes and Lord Toulson). Tort lawyers generally take the view that these issues need to be analysed separately; J. Stapleton, 'Cause in Fact and the Scope of Liability for Consequences' (2003) 119 LQR 388; M. A. Jones, A. M. Dugdale and M. Simpson (eds), Clerk \& Lindsell on Torts (London: Sweet \& Maxwell, 21st ed, 2014) 2-05.

${ }^{20}$ Bonnington Castings Ltd $v$ Wardlaw [1956] AC 613 (HL), 621 (Lord Reid).

${ }^{21}$ In line with the position adopted in this review, such cases only arise in equity in the context of private law. Similar examples exist in criminal law, but the lessons from equity provide the basis for recognising that the aims and goals of private law and criminal law are too distinct to be harmonised under a single approach.

${ }^{22}$ A similar example is provided in Twinsectra Ltd $v$ Yardley [2002] UKHL 12, [2002] 2 AC 164, [107] (Lord Millett). This is discussed further below at text to $\mathrm{n} 39$.

${ }^{23}$ J. Dietrich and P. Ridge, Accessories in Private Law (Cambridge: CUP, 2015) 39-40.

${ }^{24}$ Stapleton's terminology of 'unnecessary' cause may be more appropriate; J. Stapleton, 'Unnecessary Causes' (2013) 129 LQR 39. Also, J. Edelman, 'Unnecessary Causation' (2015) 89 Australian Law Journal 20, where it is contended that such links should not be regarded as 'causes'.

${ }^{25}$ Dietrich, above $\mathrm{n} 8,242-244$.

${ }^{26}$ Dietrich and Ridge, above n 23, 39.
} 
trying to subsume equity's approach to third party liability under a generic concept of accessory liability. It is explained further on that it is not essential for there to be a causal link between a third party's assistance and the breach of an equitable duty as 'involvement' is sufficient, ${ }^{27}$ but a requirement of a causal link is more in line with private law claims against third parties for breaches in contract and tort.

\section{The Mental Element}

In addition to the conduct element, accessory liability also requires a mental element. Davies considers whether the mental element should be based on intention, knowledge, dishonesty, unconscionability, recklessness or negligence (41-52). Intention is rejected for being too rigid and for not capturing all of those scenarios where a defendant should be held responsible (41). Those who assist in a primary wrong may be motivated by personal gain, and the harm suffered by the claimant may not be the sole purpose for their actions. There have been some attempts to define intention in a way that would include ancillary purposes, but such attempts have not been entirely convincing. ${ }^{28}$ Davies' position would help to avoid this artificiality. It is also explained in the book that negligence is not a sufficient mental element for third party liability as it would provide an unfair burden on the third party's freedom of action (52). However, it seems that recklessness may be sufficient in establishing that the defendant had the requisite levels of actual knowledge (51-53). Actual knowledge is the standard adopted by Davies for all forms of accessory liability which, when coupled with the conduct element, seems to provide an appropriate regime for capturing most forms of non-equitable accessory liability. Davies also rejects dishonesty, for being uncertain in its application and providing an unnecessary gloss to the requirement of 'knowledge' (49-50). The consequence of this analysis is that Davies would also seek a return to knowledge as the mental element in place of 'dishonest assistance' in equity (130). As will be discussed further below, ${ }^{29}$ the position taken in this essay is that a requirement of knowledge would provide insufficient protection for third parties, and so dishonesty should be retained as the relevant standard for assistance claims in equity.

\section{Defences}

The book also argues that it is possible for a knowing accessory to escape liability on the basis of justification, a widely defined defence that allows flexibility and further protection for parties who should not be held responsible. Such justifications include acting under an equal or superior right, performance of a duty, staple article of commerce, public morals and statutory justification (230-250). The justification of 'performance of a duty' will be of central importance when considering dishonest assistance. It will be explained further on that one of the most compelling reasons for requiring a stringent mental element in dishonest assistance is to protect banks, solicitors and agents who may be acting under the instructions of a primary wrongdoer. ${ }^{30}$ In effect, Davies' approach would transfer this issue from the grounds of liability

\footnotetext{
${ }^{27}$ See text to $\mathrm{n} 37$ below.

${ }^{28}$ OBG Ltd v Allan [2007] UKHL 21, [2008] 1 AC 1, [42]-[43] (Lord Hoffmann) and [191] (Baroness Hale).

${ }^{29}$ See text to $\mathrm{n} 86$ below.

${ }^{30}$ See text following $\mathrm{n} 83$ below.
} 
to a question of whether there should be a defence. There is a strong reason for being wary of this proposition, as this would place the burden of proving 'justification' on the third party. A similar shift of the burden of proof has been discussed extensively in the context of knowing receipt, and academics such as Smith have stressed that in practice this would have a profound impact in how parties approach legal proceedings. ${ }^{31}$ This concern has long been noted in equity, as evidenced by Stuart VC in Morgan v Stephens: ' $[\mathrm{t}]$ he necessities of mankind require that the fullest protection should be afforded to the character of agent, and to that protection he is entitled by the principles of this Court'. ${ }^{32}$ The tenor of this statement should make us wary of placing the burden of justification on a third party who has been involved in a breach of equitable duty.

\section{Theorising about Accessory Liability}

The most notable aspect of this book is that Davies purposely avoids providing a single theory of accessory liability. Whilst a number of principles are considered as the basis for accessory liability, it is concluded that '[ $\mathrm{n}] \mathrm{o}$ single principle appears to be conclusive' (20). Instead, Davies contends that accessory liability is an amalgamation of responsibility for losses, the protection of rights, deterrence and culpability (20-21). It is understandable why Davies has not adopted a single unifying theory. Given the current 'pockets' of accessory liability that exist in English private law, the primary task of this book is to demonstrate that there is sufficient commonality between the various strands of accessory liability for them to be unified in the first place. Other authors have taken a similar approach to such tasks. For example, in his highly influential book, An Introduction to the Law of Restitution, Birks avoided pinning the concept of unjust enrichment on a single principle. ${ }^{33}$ Just as with the law of unjust enrichment, this means that the contours and shapes of Davies' account of accessory liability can provide an essential starting point for others to explore the theoretical basis in the future. ${ }^{34}$

At the same time, just as Birks himself conceded in his later writings, there is always the potential that too much terrain has been included in the map. ${ }^{35}$ The consequence of including too much terrain is that this may serve to undermine the coherence of the concept of accessory liability. This is why a core principle would be preferable. The identification of a core principle does not preclude the relevance of the other principles noted by Davies, but it allows the boundaries and scope of the concept to be shaped by reference to the underlying principle. If, for example, liability is primarily based on the importance of the defendant's role in the primary wrong, it may be necessary to be more restrictive in the causal inquiry by excluding cases where the harm would have happened regardless of the conduct of the

\footnotetext{
${ }^{31}$ L. Smith 'Unjust Enrichment, Property and the Structure of Trust' (2000) 116 Law Q Rev 412, 434 and C. Harpum 'Knowing Receipt: The Need for a New Landmark: Some Reflections' in W.R. Cornish et al (eds) Restitution: Past, Present and Future (Oxford: Hart Publishing, 1998) 250.

${ }^{32}$ Morgan v Stephens (1861) 3 Giff 226, 236 (Stuart VC).

${ }^{33}$ P. Birks, An Introduction to the Law of Restitution (Oxford: Clarendon, rvd ed, 1989); Birks advocated a 'generic conception' of unjust enrichment, 16, further stating that ' $[\mathrm{t}]$ he best policy is to make no use of the socalled principle against unjust enrichment', 25. See also the rejection of a 'general doctrine', 27.

${ }^{34}$ Eg E. Weinrib, 'The Normative Structure of Unjust Enrichment' in C. Rickett and R. Grantham, Structure and Justification in Private Law (Oxford: Hart, 2008) 23.

${ }^{35}$ P. Birks, 'Misnomer' in W.R. Cornish et al (eds), above n 31, 7 and fn 15.
} 
accessory. ${ }^{36}$ On the other hand, if the focus is on culpability, then a stronger mental element, such as dishonesty may be required. It also means that, in establishing liability, less focus should be placed on establishing a causal link between the third party's involvement and the primary wrong. These differences, it is argued, are indeed evident when we compare dishonest assistance in equity with other instances of 'accessory liability' developed in Davies' book, as will be demonstrated in the following section.

\section{DISHONEST ASSISTANCE IN EQUITY}

There are two key features which distinguish dishonest assistance from Davies' formulation 'accessory liability'. First, in equity, the conduct element is wider than in other instances of 'accessory liability', allowing for liability to arise even in the absence of a causal link. Second, the mental element in dishonest assistance is more stringent than in other instances of 'accessory liability'.

\section{The Conduct Element; Causation}

A strong causal link between the actions of the defendant and the primary wrong is of fundamental importance in the context of many forms of third party liability, but less so in dishonest assistance. ${ }^{37}$ Two examples can be given. The first example is that a third party may dishonestly assist a breach of trust after the primary wrong has occurred. ${ }^{38}$ As Lord Millett noted in Twinsectra $v$ Yardley, ' $[\mathrm{m}]$ ost of the cases have been concerned, not with assisting in the original breach, but in covering it up afterwards by helping to launder the money'. ${ }^{39}$ It does not seem possible, however, for a third party to be liable under the tort of inducing a breach of contract where the breach occurred before the third party's involvement. ${ }^{40}$ The same is true in other situations, such as liability for assisting in a breach of copyright, ${ }^{41}$ or even for assisting in fraud. ${ }^{42}$ A possible refinement would be to argue that the actions of the third party must be causally linked with any losses suffered, rather than necessarily with the committal of the primary wrong. But even that analysis is difficult to support in light of judicial statements to the contrary, ${ }^{43}$ and also because a third party can be liable for dishonest assistance even in the

\footnotetext{
${ }^{36}$ See J. Dietrich, 'Accessorial Liability in the Law of Torts' (2011) 31 LS 231, 241-242 (Dietrich adopts the view that liability is a response to the accessory's responsibility for the legal injury suffered by the claimant, 231.)

${ }^{37}$ See R. Stevens, Torts and Rights (Oxford: OUP, 2007) 282.

${ }^{38}$ Eg Glen Dimplex Ltd v Smith [2011] EWHC 3392 (Comm).

${ }^{39}$ Twinsectra Ltd v Yardley [2002] UKHL 12, [2002] 2 AC 164, [107] (Lord Millett).

${ }^{40}$ There is obiter support for a tort of 'aiding' a breach of contract; Hemingway Securities Ltd v Dunraven Ltd (1996) 71 P \& CR 30 (Jacob J), but formulations of the tort are normally worded in such a way that would preclude liability arising. Eg 'those acts by the father can only be complained of by the plaintiffs as against the sons if the sons procured breaches of covenant by the father', Batts Combe Quarry Ltd v Ford [1942] 2 All ER 639 (CA) 640 (Lord Greene MR). Also, Law Debenture Trust Corp v Ural Caspian Oil Corp Ltd [1995] Ch 152 (CA), 170 (Beldam LJ).

${ }^{41}$ CBS Songs Ltd v Amstrad Consumer Electronics Plc [1988] AC 1013 (HL), 1058 (Lord Templeman).

${ }^{42}$ Credit Lyonnais Bank Nederland v Export Credits Guarantee Dept [2000] 1 AC 486 (HL), 499-500 (Lord Woolf MR).

${ }^{43}$ Grupo Torras v Al Sabah (2nd November 2000, CA); Casio Computer Co Ltd v Sayo [2001] EWCA Civ 661 (Tuckey LJ).
} 
absence of any loss. ${ }^{44}$ Equity's approach to the conduct element is clearly distinct from the approach taken in other instances of 'accessory liability'. As noted above, this can be attributed to the fact that equity has traditionally focused more on the mental element by requiring dishonest involvement. ${ }^{45}$ By focusing more on moral culpability and less on the responsibility of the third party, a more general question of 'assistance' in the breach of an equitable duty is appropriate as opposed to the narrower causal enquiry used elsewhere in private law.

\section{The Conduct Element; Omissions}

The second example concerns omissions. Notably, Davies does not seek to distinguish between cases of passive and active interference (23-24). This is inevitable if one is seeking to develop a regime that can incorporate accessory liability in equity where omissions liability seems to have been accepted by the judiciary. An example given in Davies' book derives from Lord Nicholls in Royal Brunei Airlines v Tan, where his Lordship discussed the liability of a solicitor who fails to tell a trustee that a particular act constitutes a breach of trust. ${ }^{46}$ This position would also appear to be supported by a comment made by Lord Walker in Customs \& Excise $v$ Barclays Bank. ${ }^{47}$ In Customs \& Excise, the question was whether a bank could owe a duty of care to prevent a customer from withdrawing funds from an account which had been the subject of a freezing injunction. Although the claim failed, Lord Walker also noted that a bank would be liable 'for breach of fiduciary duty if they shut their eyes to dishonest dealings by their customers' ${ }^{48}$ Admittedly, the language used here is not very helpful. If the money channelled through a bank account is trust money, the bank would not necessarily have owed any fiduciary duties to anyone. They certainly do not owe a fiduciary duty to their customers, ${ }^{49}$ and it would be controversial to conclude that they owe fiduciary duties merely on the basis that they know the money is the subject of a trust. ${ }^{50}$ The sensible conclusion is that Lord Walker was, essentially, discussing dishonest assistance here. It has been argued by other commentators that, where a bank is aware that trust money is being paid into a bank account, the bank will be actively assisting the breach through the provision of the bank account. ${ }^{51}$ However, that would require blurring the lines between positive acts and omissions. It would be preferable to acknowledge that the failure to prevent a breach of trust by the bank constitutes an omission. The imposition of assistance liability in cases of omissions is further supported by Glen Dimplex Home Appliances Ltd $v$ Smith, where it was concluded that the defendant who had allowed his wife to use their joint bank account as a vehicle for fraud was guilty of dishonest assistance. $^{52}$

\footnotetext{
${ }^{44}$ Novoship (UK) Ltd v Mikhaylyuk [2014] EWCA Civ 908; [2015] QB 499.

45 See text to $\mathrm{n} 10$ above.

${ }^{46}$ Royal Brunei n 1, 384.

${ }^{47}$ [2006] UKHL 28, [2007] 1 AC 181.

48 ibid, [75]. Also, Jones v Churcher [2009] EWHC 722 (QB), [2009] 2 Lloyd's Rep 94.

${ }^{49}$ Foley v Hill (1848) 2 HL Cas 28, and Wilson v Lord Bury (1880) 5 QBD 518 (CA), 531(Brett LJ); 'the relation of banker and customer, which is contract, and not trust' although it was indicated in Bank of Scotland $v$ A Ltd [2001] EWCA Civ 52 [2001] 1 WLR 751, that a bank could become a 'putative fiduciary' [37] (Lord Woolf CJ).

${ }^{50} \mathrm{Eg}$ the reception of Lord Browne-Wilkinson's suggestion that mere knowledge can create a fiduciary duty in Westdeutsche v Islington LBC [1996] AC 669 (HL) at 708-709; P. Birks, 'Trusts Raised to Reverse Unjust Enrichment' (1996) 4 RLR 1, 19-20 and R. Chambers, Resulting Trusts (Oxford: OUP, 1997) 208.

${ }^{51}$ E.P. Ellinger et al, Ellinger's Modern Banking Law, (Oxford: OUP, $5^{\text {th }}$ ed, 2011) 279. The authors cite DoddsStreeton J in Re-Engine Pty Ltd (in liq) v Fergusson [2007] VSC 57 [117].

52 [2011] EWHC 3392 (Comm).
} 
Nevertheless, it is questionable whether omissions can ever lead to liability in other areas of private law. ${ }^{53}$ For example, it is difficult to see how an omission could lead to a conclusion that a third party can be liable for inducing, or even aiding, a breach of contract. Let us say that $\mathrm{B}$ is under contract with $\mathrm{C}$, and $\mathrm{A}$ is someone whose opinion $\mathrm{B}$ greatly respects. $\mathrm{A}$ is told by B that B plans to breach his contract with $\mathrm{C}$, but A does not try to dissuade $\mathrm{B}$ from this course of action. If we are simply asking whether A has knowledge and whether there is a causal link, then this is readily satisfied in this scenario. A knew full well what was going to happen and that their failure to use their sway over B would result in a breach of contract between B and C. Under the current state of law, it would not be possible to bring a claim for inducing a breach of contract, and it is questionable whether this would be desirable. ${ }^{54}$ Something more 'substantial' should be required to hold a third party responsible for another person's breach of contract. Contract could try to follow equity by demanding a more stringent mental element, which was suggested by the language of 'malicious' interference in Lumley $v$ Gye,${ }^{55}$ but that has long been rejected as essential. ${ }^{56}$ This is why, outside of equity, it is not only necessary to have a clear causal link but also to demonstrate that the third party's positive actions led to the primary wrong.

Liability for failing to intervene could also have a profound impact in other areas of tort law. For example, there are numerous cases in negligence where the courts have rejected any potential liability against the police for failing to act despite having knowledge that a criminal was going to attack a victim. ${ }^{57}$ Another possible example is the aforementioned case of Customs \& Excise. ${ }^{58}$ The bank had knowledge that a 'wrong' was likely to occur (eg avoiding paying tax liability ${ }^{59}$ ), but permitting this to happen was not, on its own, sufficient to give rise to liability. In negligence, liability for omissions is tightly controlled and the concern would be that accessory liability could be used to circumvent these rules unless the conduct element is more narrowly defined. For accessory liability to correspond to existing private law principles, liability for failing to act should never be sufficient for establishing accessory liability. The logical conclusion is, therefore, to recognise that dishonest assistance in equity is a different form of third party liability from 'accessory liability'. An obvious consequence is that the term 'accessory' would no longer seem appropriate, and it may be preferable to label this liability for 'knowing inducement' (although for the purposes of this essay, it will continue to be referred to as 'accessory liability').

\section{The Mental Element}

One of the significant changes that would be provided by the adoption of knowledge as the mental element is that it would require the courts to move away from dishonesty as a standard

\footnotetext{
${ }^{53}$ See Dietrich and Ridge, n 23 above, 123.

${ }^{54}$ H. Carty, An Analysis of the Economic Torts (OUP: Oxford, $2^{\text {nd }}$ ed, 2010), 46-47 and Dietrich and Ridge, above n 23, 42-44.

55 (1853) 2 El \& B1 216.

${ }^{56}$ See the cases mentioned at $\mathrm{n} 9$ above and also Davies $\mathrm{n} 2$ above 156-157.

${ }^{57}$ Michael v Chief Constable of South Wales [2015] UKSC 2, [2015] AC 1732; Van Colle v Chief Constable of the Hertfordshire Police [2008] UKHL 50, [2009] AC 225; Mitchell v Glasgow City Council [2009] UKHL 11, [2009] AC 874; Osman v Ferguson [1993] 4 All ER 344 (CA).

58 [2006] UKHL 28, [2007] 1 AC 181.

${ }^{59}$ It is unclear whether this can be regarded as a 'tort'; see Total Network SL v Revenue and Customs

Commissioners [2008] UKHL 19, [2008] 1 AC 1174 [121]-[122] (Lord Mance). In any case, it would be a criminal wrong; $R$ v Hudson [1956] 2 QB 252 (CA).
} 
in equity. An interesting point that Davies raises is that dishonesty is not required for accessory liability in the criminal context which makes its application in equity, at first glance, somewhat surprising (119-120). Davies is also correct in asserting that 'dishonesty' has caused difficulty in determining the liability of accessories in equity. Whereas the Privy Council in Royal Brunei $v$ Tan seemingly recognised an objective standard of dishonesty, ${ }^{60}$ in Twinsectra $v$ Yardley the majority introduced an additional subjective limb that required the defendant to realise that they were also dishonest by the standards of others. ${ }^{61}$ The additional limb in Twinsectra made it more difficult to establish that a defendant was dishonest, in essence providing an extra level of protection for the defendant. Although the Privy Council sought to restate the Royal Brunei position in Barlow Clowes Intl Ltd v Eurotrust Intl Ltd, ${ }^{62}$ as Davies notes, this required a reinterpretation of Twinsectra that seemed to conflict with the judgments in that decision (117118). Lower courts have been left in the unenviable position of applying the Privy Council's difficult reinterpretation of a House of Lords judgment, as demonstrated by Abou-Rahmah $v$ Abacha ${ }^{63}$ In Abou-Rahmah, Arden LJ followed the Royal Brunei test, whereas Pill LJ seemed to acknowledge the Twinsectra test and Rix LJ refused to commit to either position. ${ }^{64} \mathrm{~A}$ possible reason for this apparent inconsistency is that the finding of dishonesty could have severe repercussions for those who work in the legal profession, which may provide the real reason for the conflicting versions of the test for dishonesty that has been present in equity (119). ${ }^{65}$ Notably, the Twinsectra test has been consistently applied in disciplinary proceedings against solicitors, ${ }^{66}$ whereas the Royal test has been applied in other contexts. ${ }^{67}$ It would be an understatement to call the resulting state of law unsatisfactory.

There is, therefore, appeal in Davies' proposition that knowledge, coupled with substantial cause, would provide a more suitable test for third party liability. But it is debatable whether the current state of dishonest assistance requires such a wholesale change, especially since the adoption of knowledge could potentially cause as much confusion as the current test for dishonesty. For example, the precise meaning of 'knowledge' in the context of knowing receipt has attracted its own share of criticism. ${ }^{68}$ Moreover, the uncertainty involved in the appropriate test for dishonesty might possibly be resolved by focusing on the established patterns of liability in equity. Indeed, if one looks at the case of Bodenham v Hoskyns, which has unfortunately not been cited in any of the above authorities, it is evident that the test should clearly be defined as an objective standard. ${ }^{69}$ In Bodenham, Kindersley VC was even careful to conclude that the defendant had not been guilty of 'any design of doing that which in their minds was dishonest or improper' but had nonetheless fallen below the standards imposed by the courts of equity. ${ }^{70}$ It may not be the essence of the test which is the problem, but rather the need for alternative term to 'dishonesty'. For example, the phrase of 'want of probity' appears

\footnotetext{
${ }^{60}$ Royal Brunei, above n 1, 389 (Lord Nicholls).

${ }^{61}$ Twinsectra, above $\mathrm{n} 22$, [36] (Lord Hutton).

62 [2005] UKPC 37, [2006] 1 WLR 1476.

63 [2006] EWCA Civ 1492, [2007] Bus LR 220.

64 ibid, [59a] (Arden LJ), [93]-[94] (Pill LJ), [23] (Rix LJ).

${ }^{65}$ Also, Twinsectra, above n 22, [35] (Lord Hutton) and [134] (Lord Millett).

${ }^{66}$ Bultitude v The Law Society [2004] EWCA Civ 1853, [32] (Kennedy LJ); Bryant v The Law Society [2007] EWHC 3043, [2009] 1 WLR 163, [148]-[149] and [153] (Richards LJ); Rukhsana Jabeen Kiani v Solicitors' Regulation Authority [2015] EWHC 1981 (Admin) [40] (Laing J).

${ }^{67}$ Central Bank of Ecuador v Conticorp SA [2015] UKPC 11 [9] (Lord Mance).

${ }^{68}$ Eg Lord Nicholls, 'Knowing Receipt: The Need for a New Landmark' in W.R. Cornish et al, n 31 above, 231.

${ }^{69}$ (1852) 21 LJ Ch 864, [1843-60] All ER Rep 692, affd (1852) 2 De G M \& G 903.

70 ibid, 697 (Kindersely VC).
} 
to be synonymous with dishonesty in this context, ${ }^{71}$ and may be preferable as a less 'loaded' term.

\section{The Relationship between Assistance Liability and Knowing Receipt}

The reformulation of 'dishonest assistance' to 'knowing assistance' would also seemingly harmonise the mental element for knowing receipt and accessory liability. However, this is something that Davies is keen to avoid. Davies contends that the test of unconscionability in knowing receipt makes this distinct from the mental element of knowledge that he is advocating for accessory liability (115). There are three reasons why this author would take a different interpretation of the relationship between these concepts. First, it is questionable whether it was intended for there to be a distinction between knowledge and conscience. Although some commentators have taken the position that the test for 'knowing receipt' is now one for unconscionable receipt ${ }^{72}$ unconscionability was adopted as the test for identifying the requisite knowledge, not to replace the requirement altogether. ${ }^{73}$ Furthermore, before the test for unconscionability was adopted, the most contentious issue concerned the degree of knowledge required, such as whether constructive knowledge or recklessness could be sufficient. As Birks noted, the term unconscionability appears as if it 'embraces every position in the controversy'. ${ }^{74}$ For this reason, despite the adoption of unconscionability, the current state of knowing receipt may nonetheless involve the same mental element as a reformulated action for 'knowing assistance'. ${ }^{75}$

The second reason why the reformulation of dishonest assistance would seemingly bring it closer to knowing receipt is that both are fault-based claims. In seeking to distinguish a reformulated test for 'knowing assistance' from 'knowing receipt', Davies argues that the liability of a third party recipient of trust property is 'passive' (91). But, as it currently stands, the 'conduct element' is not merely satisfied by receipt. ${ }^{76}$ Let us say that a defendant receives $£ 10,000$ in cash and a week later they are notified that the money belongs in equity to the claimant. Before the money can be transferred back to the claimant, the money is stolen from the defendant. ${ }^{77}$ In such circumstances, it would not be appropriate to hold the recipient responsible for this loss. ${ }^{78}$ This is why the test requires unconscionable receipt; the test of conscience is not merely an assessment of the mental element, but also the conduct element. ${ }^{79}$

\footnotetext{
${ }^{71}$ Starglade Properties Ltd v Roland Nash [2010] EWCA Civ 1314 [24] (Hughes LJ); Carl Zeiss Stiftung v Herbert Smith \& Co (No 2) [1969] 2 Ch 276 (CA)

${ }^{72}$ Eg G. Virgo, Principles of the Law of Restitution (Oxford: OUP, $3^{\text {rd }}$ ed, 2015) 645.

${ }^{73}$ Bank of Credit and Commerce International (Overseas) Ltd v Akindele [2001] Ch 437 (CA), 455 (Nourse LJ).

${ }^{74}$ P. Birks 'Receipt' in P. Birks and A. Pretto (eds) Breach of Trust (Oxford: Hart Publishing, 2002) 226.

${ }^{75}$ Eg M. Bryan, 'Cleaning up After Breaches of Fiduciary Duty - The Liability of Banks and Other Financial Institutions as Constructive Trustees' (1995) 7 Bond Law Review 67, when stating that conscience in this context is 'a shorthand term for actual knowledge, including recklessness and wilful blindness', 92.

76 This remains the current position despite Lord Millett's obiter comments in Twinsectra v Yardley [2002] 2 AC 164 (HL) [105]. Admittedly a proprietary claim can be 'passive' but that is clearly distinct from one based on personal liability for knowing receipt.

${ }^{77}$ If a trustee would not be liable in such circumstances, it is difficult to see how a third party recipient could be; Morley v Morley (1678) 2 Ch Cas 2, Jones v Lewis (1751) 2 Ves Sen 240 and Re Munton [1927] 1 Ch 262 (CA). ${ }^{78}$ Although the claim concerned one for dishonest assistance, Tomlinson J's discussion in Fitzalan-Howard $v$ Hibbert [2009] EWHC 2855 (QB) at [49]-[50] demonstrates that conscience is only affected at 'the point at which he could reasonably be required to have acted'.

${ }^{79}$ In Armstrong DLW GmbH v Winnington Networks Ltd [2012] EWHC 10 (Ch), [2013] Ch 156 at [277]-[286], Morris QC placed significance on the fact that the defendants had "behaved in a "commercially unacceptable"
} 
Davies seeks to further distinguish knowing receipt by noting that arguments have been made for the availability of unjust enrichment against third party recipients of trust property $(92, \mathrm{fn}$ 29). Under the unjust enrichment analysis, the recipient's liability would be strict and does not require knowledge. But even the strongest advocates of unjust enrichment have now conceded that unjust enrichment would co-exist alongside knowing receipt, not replace it altogether. ${ }^{80}$ Therefore, the adoption of unjust enrichment, which itself is highly controversial, does not avoid the issue that Davies' proposition would inevitably bring 'dishonest assistance' closer to knowing receipt.

The third reason for the position adopted here is that a more stringent mental requirement has always been applied to those who assist in breaches of equitable duties in comparison to those who knowingly received trust property. In many cases of 'dishonest assistance', a third party would receive trust property but the courts consistently drew a distinction between cases where the third party was receiving property on behalf of the trustee as opposed to where they received it for their own purposes. ${ }^{81}$ In modern times, this distinction is recognised under the concept of 'ministerial receipt' ${ }^{82}$ Regardless of the terminology, where a third party was receiving property under the instructions of the trustee, it would be the trustee to whom the third party owed obligations. ${ }^{83}$ Such defendants have traditionally been a solicitor, agent or bank who was acting on the instructions of a fiduciary or trustee. ${ }^{84}$ Third party liability was always strictly controlled and it was in these cases where the more stringent mental element of dishonesty emerged, otherwise the third party would be subject to potentially conflicting duties. Therefore, the ability of a trustee or fiduciary to engage others on behalf of the claimant provides strong support for equity's stringent mental element. ${ }^{85}$ This is because it would be too burdensome to impose competing duties on the third party unless it is evident that they are acting dishonestly. ${ }^{86}$ For example, in Gray v Johnston, Cairns LC stated 'it would be a most serious matter if bankers were to be allowed, on light and trifling grounds - on grounds of mere suspicion or curiosity - to refuse to honour a cheque drawn by their customer'. ${ }^{87}$ Similar reasoning is apparent in cases of agents such as Lockwood $v A b d y$, where it was stated that it would be 'a most fearful thing' if a sub-agent owed duties directly towards a beneficiary, but that the court would interfere where the agent was guilty of a corrupt abuse of power. ${ }^{88}$

manner'. Similarly, Arthur v Attorney General of the Turks and Caicos Islands [2012] UKPC 30 at [36]-[37] (Sir Terence Etherton). It is also notable that Lord Walker in Yeoman's Rowe Management Ltd v Cobbe [2008] UKHL 55, [2008] 1 WLR 1752 at [92] argued that unconscionability 'should always be used [] as an objective value judgment on behaviour'.

${ }^{80}$ See Lord Nicholls, 'Knowing Receipt: The Need for a New Landmark' in WR Cornish et al, n 31 above, 231 and Birks, above n 74, 213. According to A. Burrows, unjust enrichment and knowing receipt 'can happily coexist' in The Law of Restitution (Oxford: OUP, $3^{\text {rd }}$ ed, 2010), 431.

${ }^{81}$ Eg Davis v Spurling (1829) 1 Russ \& M 64, 66 (Sir John Leach). See also S. Barkehall Thomas, 'Knowing Receipt and Knowing Assistance: Where Do We Stand?' (1997) 20 The University of New South Wales Law Journal 1, 2-3.

${ }^{82}$ Jones v Churcher [2009] EWHC 722 (QB), [2009] 2 Lloyd's Rep 94 [66]-[78] (Havelock-Allan QC).

${ }^{83}$ Re Barney [1892] 2 Ch 265; Mara v Browne [1896] 1 Ch 199 (CA).

${ }^{84}$ As noted by S. Gardner, 'Knowing Assistance and Knowing Receipt: Taking Stock' (1996) 112 LQR 56, 92.

${ }^{85}$ See the justification for the rules on third party liability in Barnes v Addy (1873-74) LR 9 Ch App 244 (CA), 252 (Selborne LC).

${ }^{86}$ See C. Mitchell, P. Mitchell and S. Watterson, Goff \& Jones: The Law of Unjust Enrichment (London: Sweet \& Maxwell, $8^{\text {th }}$ ed, 2011) 28-04.

87 (1868) LR 3 HL 1, 12. Also, Hartga $v$ The Bank of England (1796) 3 Ves Jr 55, 58 (Loughborough LC). 88 (1845) 14 Sim 437, 441 (Shadwell VC). This rule is well established; in Myler v Fitzpatrick (1822) 6 Madd 360, 360 (Sir John Leach) it was stated that '[a] mere agent is to account to his principal only'. Also, Nickolson $v$ Knowles (1820) 5 Madd 47, cited with approval in Carl Zeiss Stiftung v Herbert Smith \& Co (No 2) [1969] 2 Ch 276 (CA) 299 (Sachs LJ). 
This limitation has not just been applied in cases involving suspicions, but also where there is knowledge that a primary wrong is being committed. Re Blundell is one such example. ${ }^{89}$ In that case, Stirling $\mathbf{J}$ acknowledged that the defendants had knowledge that the trustee had committed a breach of trust, but this was not sufficient to hold them liable. This decision was a key authority in Carl Zeiss Stiftung v Herbert Smith \& Co (No 2) $)^{90}$ as well as Re Montagu's Settlement Trusts, ${ }^{91}$ and both cases have been important in the development of 'dishonesty' as the required mental element. ${ }^{92}$ Another instance is Brinsden $v$ Williams, where the solicitors were aware that the trustees were making an investment in breach of trust but that this alone 'did not implicate them in a breach of trust' as they were 'merely carrying out the directions of their principal in the matter' ${ }^{93}$ It is, thus, clearly established that mere knowledge alone cannot be sufficient to make a third party liable for assisting a breach of equitable duty. Furthermore, it would be undesirable if authorities concerning the mental element required in equity were to be cited in claims against third parties outside of equity, especially given Davies' (convincing) argument that mere knowledge is sufficient for accessory liability in contract (158-160) and tort (206-209)..$^{94}$

\section{LESSONS FROM THIRD PARTY LIABILITY IN EQUITY}

Important lessons can be drawn from equity's approach to third party liability. It has been so far noted that in equity the focus is on moral culpability as it enables the courts to protect the operation of equitable duties. The requirement of dishonesty provides the basis for imposing liability on a third party even in the absence of a causal link between a third party's assistance and the primary wrong, whilst at the same time facilitating the trustee or fiduciary's ability to engage with third parties. But where stronger causal links can be found, these justifications for the requirement of dishonesty no longer apply. The claim for knowing receipt, discussed in the preceding section, provides a clear example where the third party's actions will have a clear causal connection with the loss of trust property. That causal connection will be much stronger than the connection between one who assists in a breach, and as a result there is no requirement for dishonesty. It is also notable that, in the few cases where a third party has procured a breach of trust, the requirement was merely for knowledge rather than dishonesty. For example, in Fyler $v$ Fyler it was concluded that the third parties had not acted fraudulently, but liability was satisfied by their knowing inducement of a breach of trust. ${ }^{95}$ Although Lord Nicholls' formulation of dishonest assistance in Royal Brunei Airlines $v$ Tan included procuring a breach of trust, it is questionable whether 'dishonesty' is required where there is a strong causal link in the form of actively causing a breach of trust. ${ }^{96}$

\footnotetext{
89 (1888) 40 Ch D 370 (Ch).

${ }^{90}$ [1969] 2 Ch 276 (CA).

91 [1987] Ch 264 (Ch), 280-281 (Megarry VC).

92 Royal Brunei, above n 1, 388 (Lord Nicholls).

93 [1894] 3 Ch 185 (Ch). See also the position of the solicitors in Bagnall v Carlton (1877) LR 6 Ch D 371 (CA), 409 (Cotton LJ) who knew that a company prospectus did not disclose all of the necessary information, but who were not regarded as having any intention to be party to a fraud.

${ }^{94}$ It is evident that inducing a breach of contract does not require dishonesty; Boulting $v$ Association of Cinematograph Television and Allied Technicians [1963] 2 QB 606 (CA), 640 (Upjohn LJ), where it was stated that a trade union 'cannot be accused of dishonesty or corruptness... because of their trade motives'.

95 (1841) 3 Beav 550. Also, Midgley v Midgley [1893] 3 Ch 282 (CA) and Eaves v Hickson (1861) 30 Beav 136.

96 Royal Brunei n 1, 392.
} 
Equity has also developed ways of finding third parties liable even where no primary wrong occurs, but where a third party has actively taken control over the claimant's interests. Notably, liability under these duties can be established in the absence of dishonesty. This is illustrated by the concept of 'trustee de son tort' where a third party, who is not initially a trustee, takes on the role of acting as a trustee. In such cases, the third party can be held liable for knowingly intermeddling in trust affairs. ${ }^{97} \mathrm{~A}$ further example is provided by the other form of liability explored in Davies' book, namely breach of confidence. The traditional scope of this claim was that liability would be imposed on the basis of a breach of the claimant's property rights or contractual rights. ${ }^{98}$ In breach of confidence cases, liability has arguably been extended to third parties even in the absence of any primary wrong. ${ }^{99}$ At times, the courts have created questionable breaches of primary obligations so as to enable claims against third parties; for example, holding that those attending a lecture were parties to an implied contract with the lecturer, ${ }^{100}$ or that information of the stock market was a form of property. ${ }^{101}$ This ability to impose a duty on a third party was more accurately captured in Lord Goff's judgment in the Spycatcher case where his Lordship concluded that a third party who receives confidential information would be subject to a free-standing duty of confidence. ${ }^{102}$

A final example can be illustrated by considering the liability of banks. As mentioned above, ${ }^{103}$ when a bank receives trust property on behalf of a trustee, the bank is not subject to the test for knowing receipt. So long as the bank acts in accordance with the trustee's instructions, they are subject to the test for dishonest assistance. But where the bank would step outside of the trustee's instructions (for example attempting to set-off the credit in the trust account with the debit in the trustee's personal account), the bank would become liable to the beneficiaries so long as they knew about the existence of the trust. ${ }^{104}$ The precise classification of such claims is debatable, but it is difficult to see how these claims can be fitted into accessory liability as liability does not depend upon a breach of duty by the trustee, ${ }^{105}$ nor does it easily fit within any of the other modern forms of third party liability in equity. ${ }^{106}$ This reveals an important concern, which is that the concept of 'accessory liability' could conceal the various degrees of 'involvement' that a third party can have in interferences with pre-existing equitable rights. As a result, the development of a unified concept of accessory liability may unduly inhibit the ability of the courts to reach third parties in the absence of primary wrongs or could lead to fictitious 'primary wrongs'. Fraudsters will continually seek to find new ways to benefit at the disadvantage of others, and the courts of equity have always strived to adapt to such behaviour. This is one of the reasons for equity's increased role in commercial cases. ${ }^{107} \mathrm{An}$ example given by Gardner is where the trustee honestly relied on the probity and competence of a third party but where the third party acted dishonestly. In such cases, there would be no

\footnotetext{
${ }^{97}$ Soar v Ashwell [1893] 2 QB 390 (CA). A similar principle is the executor de son tort; Sharland v Mildon (1846) 5 Hare 469 and Ex Parte Jolliffe (1845) 8 Beav 168.

98 See R.G. Hammond, 'The Origins of the Equitable Duty of Confidence' (1979) 8 Anglo-Am L Rev 71.

${ }^{99}$ T. Aplin et al, Gurry on Breach of Confidence (Oxford: OUP, $2^{\text {nd }}$ ed, 2012) 2.04.

${ }^{100}$ Abernethy v Hutchinson (1825) $1 \mathrm{H} \& \mathrm{Tw} 28,40$ (Eldon LC).

${ }^{101}$ Exchange Telegraph Company Limited v Gregory \& Co [1896] 1 QB 147 (CA), 153 (Lord Esher MR).

102 Attorney General v Times Newspapers Ltd [1990] 1 AC 109 (HL), 281.

${ }^{103}$ See text to $n 83$ above.

${ }^{104}$ C. Harpum, 'The Stranger as Constructive Trustee: Part 1' (1987) 102 LQR, 135-139; eg Bank of New South Wales v Goulburn Valley Butter Company Pty Ltd [1902] AC 543 (HL), 550 (Lord Davey).

105 Nor would it be a breach of trust where a broker misappropriated trust property, eg Speight v Gaunt (1883) 9 App Cas 1 (HL).

${ }^{106}$ Harpum, ibid, labelled this inconsistent dealing, 130. Dietrich and Ridge take the view that inconsistent dealing is a distinct form of liability; above $\mathrm{n} 23,202-204$. It has even been contended that this is an instance of knowing receipt; Barkehall Thomas, above $\mathrm{n} 81,2$.

${ }^{107}$ Eg P. J. Millett, 'Equity's Place in the Law of Commerce' (1998) 114 LQR 214, 215-218.
} 
breach of trust and, hence, no primary wrong. Gardner contends that the third party should be held liable as the defendant 'has just as much harmed the jural rights comprising the trust as if there were a breach'. ${ }^{108}$ Although Davies argues that common law claims such as negligence or deceit may be available, those claims are more limited in scope than those available in equity. ${ }^{109}$ Where a third party is in the position to fully influence the unsuspecting duty holder in equity, it would seem to be in line with equity's approach to hold the third party accountable for knowingly interfering with the beneficiary's rights due to the strong causal link between the dishonesty of the third party and the loss of the trust property.

\section{JUSTIFYING EQUITY'S UNIQUE APPROACH}

There is certainly a case for harmonising many forms of accessory liability but, arguably, a different approach is required where the third party's acts involve the infringement of equitable rights. Davies argues in this book, convincingly for this author, that one should not distinguish equity from common law on the basis that the rights are often proprietary in nature (96-100). Furthermore, Davies makes a convincing argument that the mere historical distinction of equity and common law does not justify continued differences between these two streams of law. But even those who support the fusion of both bodies of law acknowledge that some important distinctions remain. ${ }^{110}$ Nonetheless, if equity is to retain its focus on the more stringent mental requirement of dishonesty, there needs to be a reason for its unique approach to dishonest assisters. It has been suggested here that the unique nature of equitable duties provides sufficient justification for recognising that dishonest assistance is a distinct concept from 'accessory liability', despite the familial resemblances between the two concepts. As noted earlier, ${ }^{111}$ equitable duties arise where one party has control over the interests of another and which differentiates equitable rights from other rights in private law. ${ }^{112}$ Equity's formulation of dishonest assistance is important in ensuring the operation of these duties for two reasons.

The first reason is the need to protect the vulnerability of claimants where a trustee or fiduciary has control over their interests. ${ }^{113}$ To quote one judge, this is reflected in 'the general rule that equity demands higher standards of behaviour than the common law'. ${ }^{114}$ As it has been demonstrated in this essay, a significant benefit which is afforded by equity's requirement of dishonesty is that it justifies liability even in the absence of a causal link between the assistance the primary wrong. To quote Moore: 'we can relax our normal causation requirement (from causing to mere aiding) only because of the high level of culpability with which the aider

\footnotetext{
108 Gardner, above n 84, 68 .

${ }^{109}$ A beneficiary's right to sue in negligence was denied in Rae v Meek (1889) 14 App Cas 558 (HL) and Brinsden $\mathrm{n} 93$ above. There is some later authority to support a claim by beneficiaries, Ross v Caunters [1980] Ch 297 (Ch) and Baden, Delvaux and Lecuit and others v Société General [1993] 1 WLR 509 (Ch) but such a claim is not generally available; White v Jones [1995] 2 AC 207 (HL). Deceit is also narrower and may involve a more onerous mental requirement; Nocton v Lord Ashburton [1914] AC 932 (HL), 953 (Viscount Haldane LC). Neither claim would provide the basis for an account of profits against the third party.

${ }^{110}$ Eg A. Burrows, 'We Do This at Common Law But That in Equity' (2002) 22 OJLS 1.

${ }^{111}$ See text to $\mathrm{n} 4$ above.

112 Trusts generally fit within this concept, so too fiduciary duties, and even cases of breach of confidence as well.

${ }^{113} \mathrm{Eg}$ 'The distinguishing obligation of a fiduciary is the obligation of loyalty. The principal is entitled to the single-minded loyalty of his fiduciary.' Bristol and West Building Society v Mothew [1998] Ch 1 (CA), 18 (Millett LJ)

${ }^{114}$ Twinsectra Ltd v Yardley [2002] UKHL 12, [2002] 2 AC 164, [132] (Lord Millett).
} 
acts'. ${ }^{115}$ By analogy, equity's formulation of dishonest assistance is appropriate in relaxing the causal requirements where the third party has acted with a high level of culpability. For this reason, dishonesty is a preferable mental state as opposed to mere knowledge. But duties outside of equity do not involve the same level of vulnerability and therefore they do not require the same level of protection. It also seems that the common law courts have sought to avoid the difficulties of focusing too much on the defendant's mental state. ${ }^{116}$ Therefore, liability outside of equity only arises where there is a clear causal link between the actions of the third party and the primary wrong. This also means that there is no need for the common law to require a high level of moral culpability, which is reflected in the requirement of knowledge.

The second reason for equity's requirement of dishonesty is that those who owe equitable duties need to have the power to engage with third parties. As Shadwell VC noted in Lockwood v Abdy, 'in cases where gentlemen act as trustees, they must, of necessity, employ solicitors, receivers, bankers, and agents of various kinds'. ${ }^{117}$ The ability to engage third parties would be undermined if equity imposed liability on third parties for mere knowing involvement in a breach of equitable duty. Indeed, much of the discussion in Barnes $v$ Addy focused heavily on the need to protect third parties, as opposed to the need to protect the interests of beneficiaries. ${ }^{118}$ For example, in justifying equity's approach to the liability of third parties, Selborne LC stated that ' $\mathrm{i}[\mathrm{f}$ those principles were disregarded, I know not how any one could, in transactions admitting of doubt as to the view which a Court of Equity might take of them, safely discharge the office of solicitor, of banker, or of agent of any sort to trustees'. ${ }^{119}$ Again, the approach taken at common law is distinguishable, as legal obligations are more readily compartmentalised outside of equity. Since third parties will not be held responsible for mere involvement or even for merely assisting breaches of common law duties, responsibility is more readily imposed on third parties for positively causing a breach of duty even in the absence of dishonesty. Davies' formulation of accessory liability seems appropriate for such instances of liability, but the unique approach taken in equity requires the recognition that dishonest assistance is a separate legal concept.

\section{CONCLUSION}

It has been argued that dishonest assistance cannot, and should not, be accommodated within Davies' formulation of accessory liability. It should also be noted, however, that (with some possible modifications, such as precluding liability for omissions) Davies has provided a compelling case for bringing together a number of hitherto heterogeneous forms of third party liability. The importance of bringing together the various strands of accessory liability is thoroughly explained not only in the early chapters but also throughout the book. It is worth restating that this is an ambitious project which is more than impressive in its accomplishments. There will inevitably be areas where other commentators seek to modify elements of the concept of accessory liability, and it may be preferable for this to be labelled 'knowing inducement'. Such debate can only serve to strengthen the future development of assistance

\footnotetext{
115 See Moore, above n 7, 139.

${ }^{116}$ See M. Lobban, 'Intentional and Economic Torts' in W. Cornish et al, The Oxford History of the Laws of England: Volume XII: 1820-1914 Private Law (OUP: Oxford, 2010), 1049 -1060 and Carty, above n 54, 31; ' $[\mathrm{t}]$ his was in line with the late nineteenth-century distaste for inquiry into the subjective state of mind for liability purposes'.

117 (1845) $14 \operatorname{Sim} 437,441$.

${ }^{118}$ Barnes v Addy (1873-74) LR 9 Ch App 244 (CA).

119 ibid, 252 (Selborne LC).
} 
liability, as for too long these rules have remained disparate and incapable of a wider analysis. If the courts were to attempt to unite the various forms of third party liability, the book will stand as a key source in guiding the shape of this form of liability. Most importantly, the clarity and thoroughness of Davies' book should reassure the courts that such a task is feasible. Although this review has noted some areas of disagreement, the premise of exploring the relationship between the disparate forms of third party liable is a more than worthwhile endeavour.

The main source of disagreement for this writer is whether equity can so easily be accommodated with other forms of third party liability in private law. It has been argued that dishonest assistance does not involve the same conduct element as other forms of third party liability which are included in Davies' book. Liability can arise for 'weak' causal links in dishonest assistance claims such as where a third party fails to intervene. It is also the case that liability can arise for involvement which arises 'after the event', which undermines Davies' suggestion that there must be a causal link between a third party's conduct and a primary wrong. Furthermore, it is well established that mere knowledge of involvement in a breach of equitable duty is not sufficient and that dishonesty is instead required. Finally, as explained above, it is evident that a primary wrong is not always necessary in equity for a third party to be regarded as responsible for losses caused to the claimant. Given the ever-creative and new forms of fraud, it would be undesirable for the courts to be kept within such a rigid straightjacket. For accessory liability to become an established private law concept, it is important that it does not try to do too much and also that its acceptance does not lead to unforeseeable consequences. In this author's view, more cohesion would be achieved in the concept of accessory liability if equity's action for dishonest assistance was removed from its ambit. 